\title{
Roman, Historical and Contemporary Legal Access to Water as Object of Public Relations ${ }^{1}$
}

\section{Michal Maslen}

\begin{abstract}
This paper analyses the Roman water law defining water as a natural resource vital for proper working and functioning of the society. Subsequently, it deals with the notion of water in the medieval Hungarian law in terms of legal relations and, last but not least, analyses water as an object of the state strategic interests' protection and covers the responsibilities of an individual and the state for the efficient, economical and sustainable use of water.
\end{abstract}

Key Words: Roman Law; Medieval Hungarian Law; International Public Law; Water Law; Water; Recycling; Purposeful Sustainable and Economical Use of Water; the Slovak Republic.

\section{Introduction}

These days, people seem to be unaware of their luckiness involving access to clean water in relatively unlimited volume by simply turning a water tap. Households, in general, have access to clean and drinking water. This state is the result of scientific and technological development that has only been going on for about 100 years. The well-being that water provides us with, however, may not be the lasting phenomenon considering the pressure of the growing population, use of water in agriculture and industry, and ever more frequent periods of drought. The issue of used water recycling and applying efficient wastewater treatment and water conservation technologies in the country should, therefore, be given priority. Medieval society has never had access to water in the extent that we are used to these days. However, they were well aware of the importance of clean water in the wells that provided water for the population, and the accusations of well water poisoning were nothing extraordinary. Most of the cities in the Western Europe used water distribution

1 The presented scientific study was carried out within the Project of the Slovak Research and Development Agency entitled "Roman-canonical Influences on the Slovak Public Law", in the Slovak original "Rímsko-kánonické vplyvy na slovenské verejné právo", project No. APVV-17-0022, responsible researcher doc. JUDr. Mgr. Vojtech Vladár, PhD. 
systems on the principles of aqueducts built during the Roman Empire. The ancient Romans were also aware of the need of water supply and public access to clean water through aqueducts that often transported water from mountain areas to towns and cities. They also constructed sewer systems - some of them very remarkable - foundations of which have been used to these days. ${ }^{2}$

The Roman skills in mastering and building water structures and, in particular, long-distance aqueduct systems gave rise to urban culture characterized, in particular, by public water supply systems providing access to water intended for bathing, and the development of both public and private areas. On the contrary, in the rural areas, this facilitated the expansion of the Roman Empire along the Mediterranean Sea and the development of irrigation technologies between regions of different cultural and geological backgrounds. The supply and regulation of water and irrigation systems using various fountains, spas and leisure pools have also become an important policy tool for the ruling elite. High-quality access to water has thus enhanced political popularity of governing and administrative elite, especially through the funds that the government has allocated, controlled and spent on the construction of water infrastructure. The Roman Empire and, to a large extent, also the Byzantine Empire had lasted so long also thanks to conscious handling of water resources and to political and administrative decisions stressing the importance of access to water and sanitation services in urban and rural areas. However, it must be added that, in the context of water management, the Romans shouldn't be idealized as discoverers of the importance of water and sanitation services for the society. Still, it is necessary to acknowledge their contribution in acquiring and developing the technologies of the territories conquered. In the Roman Egypt, they assumed the legacy of the Pharaohs and the Ptolemaic in the area of tax system related to water regime on the Nile River. In the Middle East, Spain and the North Africa, they acquired and maintained the already existing and, in fact, giant irrigation system. Water, irrigation and sanitation systems were the driving force of the state and administration power during the Roman

\footnotetext{
2 For more details, see DALE BRITTAIN, C. Water in the Middle Ages. In: Life in the Middle Ages [online]. 2015-05-28 [cit. 2019-12-09]. Available at: http://cdalebrittain.blogspot. com/2015/05/water-in-middle-ages.html.
} 
Empire. ${ }^{3}$ An example is the legislation of the Roman Spain dating back to the $2^{\text {nd }}$ Century $\mathrm{AD}$, known as lex rivi Hiberiensis. This legislation addressed the regulation of water regime on the Ebro River in Spain, supplying water to the towns of Caesaraugusta (presently Zaragoza) and Cascantum (presently Cascante) and to the adjacent rural areas. The above-mentioned cities shared a canal - known as riuus Hiberiensis. Said legislation was adopted upon the initiative of the neighbouring rural areas and the intervention of provincial administration headed by Augustus Alpinus. It provided information on procedural aspects of irrigation law, court oaths, court formulae and legal documents ${ }^{4}$ of that time. From the material point of view, the legislation followed the irrigation right in the irrigation system of the Ebro River valley, the main irrigation arm of which was approximately $20 \mathrm{~km}$ long and supplied users of three administrative districts. ${ }^{5}$

The medieval Hungarian law perceived water as an object of legal relations mainly through the right in rem. Water was a benefit related to property ownership. The grounds of the medieval property ownership relations were the fief systems. It was the basis of feudal system in which the monarch, as the head of the state, through his iuris regii, left to permanent, hereditary possession precisely specified real estate and rights to individual representatives of the aristocracy and the church, in form of a solemn unilateral legal act known as donation. Donation was to appreciate the past and also future manifestations of loyalty and devotion of the recipient who was usually a man. However, the Hungarian customary law did not exclude donation to a woman, either. Donation thus represented the legal title of acquisition to donated property and related rights. Acquisition of ownership was completed by an act known as statuti, i.e. a handover of the property to the recipient, which had to be done within one year from donation. ${ }^{6}$

3 For further details, see WILSON, A. Water, Power and Culture in the Roman and Byzantine Worlds: An Introduction. Water History [online]. 2012, vol. 4, no. 1, pp. 2-3 [cit. 2019-1209]. ISSN 1877-7244. Available at: https://doi.org/10.1007/s12685-012-0050-2.

4 For more details, see LLORIS, F. B. An Irrigation Decree from Roman Spain: The Lex Rivi Hiberiensis. The Journal of Roman Studies [online]. 2006, vol. 96, pp. 147-197 [cit. 201912-09]. ISSN 1753-528X. Available at: https://doi.org/10.3815/000000006784016242.

5 For further details, see WILSON, A. Water, Power and Culture in the Roman and Byzantine Worlds: An Introduction. Water History [online]. 2012, vol. 4, no. 1, pp. 2-3 [cit. 2019-1209]. ISSN 1877-7244. Available at: https://doi.org/10.1007/s12685-012-0050-2.

6 For further details, see LACLAVÍKOVÁ, M. and A. ŠVECOVÁ. Pramene práva na území Slovenska I.: Od najstarších čias do roku 1790 [Sources of Law in Slovakia I.: From the Oldest 
This system also covered regal rights that formed a set of acquisition rights of the monarch. These included, inter alia, incomes from the exchange and minting of coins, income from mining, salt production, toll collection and thirtieths collection. The king granted smaller regal rights to nobles and towns. These included, in particular, the right of market, toll, brewery, wine tap, meat cut, mill and the like. ${ }^{7}$ Regal rights were enforced by the Roman-German monarchs in the $12^{\text {th }}$ Century as a special category within the res publicae, said to be owned exclusively by the emperors themselves.

This category follows two basic groups distinguished in the medieval law. Under the influence of the Roman law, there was a distinction between private property (res in patrimonio) and private property (res extra patrimonium). ${ }^{8}$

Therefore, regal rights included the right to use water for specific economic purposes, such as: brewery, wine growing or mill production. Medieval documents distinguish water and watercourses, as well as ponds. Thus, it can be concluded that the term water encompassed water areas and water springs in today's legal sense, while watercourses included brooks, rivers and other formations through which water flowed, as is the case in today's water management legislation. Ponds were perceived with reference to fish production, as for example, the Deed of 28 February 1302, by which Ladislav V. gives the County of Nitra to Palatine Matthias, son of the former Palatine Peter of the Csak family, stating that the monarch gives to Matthias the Nitra County with all the villages, towns, heritage, customs and all benefits, forests, meadows, fields, both cultivated and rough, waters and watercourses, ponds there found, as well as any essentials belonging to that county to his permanent possession with hereditary right. ${ }^{9}$

Times till 1790]. 1. vyd. Trnava: Typi Universitatis Tyrnaviensis, 2007, p. 252. ISBN 97880-8082-153-1.

7 For more details, see Regál [Regal]. In: Pamiatky na Slovensku [Sights in Slovakia] [online]. 2019 [cit. 2019-12-09]. Available at: http://www.pamiatkynaslovensku.sk/regal.

8 For more details, see VOJÁČEK, L., J. KOLÁRIK and T. GÁBRIŠ. Československé právne deji$n y$ [Czechoslovak History of Law]. 2. preprac. vyd. Žilina: Eurokódex, 2013, p. 138. ISBN 978-80-89447-99-2.

9 For further details, see LACLAVÍKOVÁ, M. and A. ŠVECOVÁ. Pramene práva na území Slovenska I.: Od najstarších čias do roku 1790 [Sources of Law in Slovakia I.: From the Oldest Times till 1790]. 1. vyd. Trnava: Typi Universitatis Tyrnaviensis, 2007, p. 259. ISBN 97880-8082-153-1. 
Water is similarly perceived by the Deed of Louis I. of Budin of 10 October 1344 , by which, upon the request of Nicholas, the son of Julius, he donated to him and his brother George the property of Tesárske Mlyňany and, at the same time, promoted both to aristocratic rank. By this document, the sovereign donated the property of Tesárske Mlyňany to these persons with all appertaining benefits, i.e. the land, both cultivated and rough, forests, meadows, groves, plains, waters and watercourses, mills and places designated for milling and all other assets found within actual and recent boundaries under any name, as owned by the previous holders. ${ }^{10}$

Similarly, the Deed of Sigismund of Luxembourg issued on 14 August 1399, in Ružomberok, by which he donated the village of Radvaň to the late Matthias for his loyal services to his yet unborn child provided it will be a boy, joined all the donated assets and utilities, i.e. cultivated and rough fields, forests, hills, vineyards, waters and watercourses. ${ }^{11}$

The above-mentioned Roman and historical legal knowledge has also been reflected in contemporary science of water which distinguishes the biological and health function of water, as well as its aesthetic and cultural function. The biological importance of water is perceived through its ability to provide nutrition to people, plants and animals, and, at the same time, to act as a climate and soil agent. The health function of water involves personal and public human hygiene, environmental cleaning, garbage disposal, heating, air conditioning and others. The essence of the cultural and aesthetic function of water is its power to enhance the aesthetic value of the landscape.

\section{Strategic functions of water in the Slovak legislation}

The above-mentioned functions of water were also reflected by the Slovak lawmaker in defining the properties of water in the Act No. 364/ 2004 Coll. on Waters, and on Amendment to the Act of the Slovak National Council No. 372/1990 Coll. on Offenses, as amended (the so-called Wa-

\footnotetext{
${ }^{10}$ For further details, see LACLAVÍKOVÁ, M. and A. ŠVECOVÁ. Pramene práva na území Slovenska I.: Od najstarších čias do roku 1790 [Sources of Law in Slovakia I.: From the Oldest Times till 1790]. 1. vyd. Trnava: Typi Universitatis Tyrnaviensis, 2007, p. 261. ISBN 97880-8082-153-1.

${ }^{11}$ For further details, see LACLAVÍKOVÁ, M. and A. ŠVECOVÁ. Pramene práva na území Slovenska I.: Od najstarších čias do roku 1790 [Sources of Law in Slovakia I.: From the Oldest Times till 1790]. 1. vyd. Trnava: Typi Universitatis Tyrnaviensis, 2007, p. 264. ISBN 97880-8082-153-1.
} 
ter Act; hereinafter referred to as the "Act No. 364/2004 Coll."). Under $\S 1$ Section 1 of the Act No. 364/2004 Coll., "Water, as a vital component of the environment, is an irreplaceable substance and natural resource that is of strategic importance for the security of the state, whose deficiency may endanger life and health of the population, or endanger the fulfilment of the essential functions of the state."

In the above-stated provision of the Act No. 364/2004 Coll., the lawmaker linked to the statement of environmental protection under the Act No. 17/1992 Coll. on the Environment (hereinafter referred to as the "Act No. 17/1992 Coll."). According to $\S 2$ of this Act, the environment is everything that creates natural conditions for the existence of organisms, including human beings, and is a prerequisite of their next development. Its components are mainly air, water, rocks, soil and organisms. Article 1 Section 1 of the Act No. 364/2004 Coll. also follows the statement of $\S 6$ of the Act No. 17/1992 Coll. on sustainable development, under which "Sustainable development of society is development that provides current and future generations with ability to meet their vital needs, while not reducing the diversity of nature and preserving natural functions of ecosystems."

The national law of the Slovak Republic qualifies water as a natural resource, i.e. an object recognized by $\S 7$ of the Act No. 17/1992 Coll., as follows: "(1) Natural resources are those parts of living or inanimate nature that people use or can use to satisfy their needs. [...] (2) Renewable natural resources have the ability to recover partially or fully, either by themselves, or with the help of humans, while being gradually exhausted. Non-renewable natural resources extinguish by being exploited." This is an essential distinction between natural sciences and legal regulations. While natural sciences explore water in its cycle, role and functions it performs in nature, the legislation assesses it primarily from the point of view of meeting human basic needs. In defining the terms water and natural resources, legislation does not take into account the ability of the natural resource to circulate in nature; i.e. it does not focus on water cycle, but only defines renewable or non-renewable character of it.

The definition of water quality to the Act No. 364/2004 Coll. also reflects its economic functions in the state which are legally important in terms of meeting public needs and promoting its interests. For this reason, the lawmaker has enforced the administrative view of water functions in the state, in the wording of $\S 1$ Article 1 of the Act No. 364/2004 Coll. Under the Article 1 Section 3 of the Constitutional Act No. 227/2002 
Coll. on State Security at the Time of War, State of War, State of Emergency and State of Crisis (hereinafter referred to as the "Constitutional Act No. 227/2002 Coll."), "Security is a situation in which peace and security of the state, its democratic order and sovereignty, territorial integrity and inviolability of state borders and fundamental rights and freedoms are maintained, and in which the lives and health of persons, property and the environment are protected."

According to the Article 1 Section 1 of the Constitutional Act No. 227/2002 Coll., "The Slovak Republic exercises state power to maintain peace and security of the state, in particular, in defending its sovereignty, territorial integrity, inviolability of borders and democratic order, protecting human life and health, fundamental rights and freedoms, property and environment, and fulfilling obligations resulting from the membership in the organization of mutual collective security and international treaties which the Slovak Republic undertook to fulfil. To declare war or to declare a state of war, state of emergency and state of crisis is only possible under the conditions laid down by this Constitutional Act." Although Article 1 Section 1 of the Constitutional Act No. 227/2002 Coll. does not explicitly mention the rule of law, it partially lists its individual attributes, such as: democratic order, protection of life and health, fundamental rights and freedoms and fulfilment of obligations under international treaties. Hence, security is among the prerequisites of enforcing the attributes of the rule of law.

If, under $\S 1$ Section 1 of the Act No. 364/2004 Coll., water is a vital substance and natural asset strategic for the security of the state, and if the security of the state is, under the Article 1 Section 1 of the Constitutional Act No. 227/2002 Coll., the prerequisite for enforcing its legal nature, then water protection is among the key requirements of the legal state, such as the Slovak Republic is under the Article 1 of the Constitution of the Slovak Republic. According to the above-stated constitutional provision of the Slovak Republic, "(1) The Slovak Republic is a sovereign, democratic state governed by the rule of law. It is not bound to any ideology or religion. [...] (2) The Slovak Republic acknowledges and adheres to general rules of international law, international treaties by which it is bound, and its other international obligations."

\section{Efficient, economical and sustainable use of water}

The court case-law in Slovakia also responded to the interpretation of the provisions of the Act No. 364/2004 Coll. on the efficient, economical and 
sustainable use of water. The constitutional basis of such water use is the second sentence of the Section 4 of the Article 1 of the Constitution of the Slovak Republic, according to which "The Slovak Republic protects and improves its assets, makes economical and efficient use of mineral resources and natural heritage for the benefit of its citizens and subsequent generations." In addition to this, the regulation of water use is also covered by the Article 44 Sections 2, 3 and 4, according to which "(2) Everyone shall have a duty to protect and to improve the environment and to foster cultural heritage. [...] (3) No one must endanger or harm the environment, natural resources and cultural monuments above the state-prescribed limit. [...] (4) The state shall care for economical exploitation of natural resources, ecological balance and effective environmental policy, and shall secure protection of determined sorts of wild plants and wild animals." It can be stated that the amendment of the Article 4 Section 1 the second sentence and the Article 44 Section 4 of the Constitution of the Slovak Republic is a kind of duplication of the state's obligation in the use of natural resources, with obligation also being embedded in the Act No. 364/2004 Coll. First of all, it involves the purpose and subject of the legal regulation of the Act No. 364/2004 Coll. in $\S 1$ Section 2 letter c) of this Act. ${ }^{12}$ This general statement is followed by the statement of the state water management authority on permitting water offtakes. According to $\S 21$ Section 7 of the Act No. 364/2004 Coll., "In granting permits for water offtake, the national water management authority shall be bound by the following: (a) water from a watercourse determined by its flow volume must allow the general use of surface waters and secure watercourse functions and the conservation of aquatic ecosystems existing therein (hereinafter referred to as the "minimum residual flow"), [...] (b) underground water determined by the level of underground water allowing the sustainable use of water resources and the proper functioning of the related water formations (hereinafter referred to as the "minimum underground water level"), and by the Ministry's decision on approving the final report including the calculation of underground water volumes."

The above-cited act provision was amended by the Act No. 409/2014 Coll. Said Act completed § 21 Section 7 letter b) of the Act No. 364/2004 Coll. with the words "and by the Ministry's decision on approving the final report including the calculation of underground water volumes." The original wording of this provision did not include the obligation of the state

\footnotetext{
12 Under said provision, "This law creates the conditions for [...] (c) efficient, economical and sustainable use of waters..."
} 
water management authority to consider the decision of the Ministry of the Environment of the Slovak Republic on approving the final report including the calculation of underground water volumes under $\S 18$ of the Act No. 569/2007 Coll. on Geological Works (the so-called Geological Act; hereinafter referred to as the "Act No. 569/2007 Coll.").

The lawmaker justified this amendment as follows: "The amendment of the provision in $\S 21$ Section 7 letter $b$ ) has been drafted following $\S 4 b$ Section 1, under which underground water detection is carried out in underground water formations and hydrogeological regions by hydrogeological survey, the outcome of which is the Ministry's decision on approving the final report including the calculation of underground water volumes, and on restricting the blocking of underground waters not being used; permissions shall be issued as necessary, and not according to the volume available." ${ }^{\prime 13}$ The $\S 4 \mathrm{~b}$ Section 1 of the Act No. 364/2004 Coll. regulates the detection of the occurrence, volume, regime and quality of underground waters, under which "Detected occurrence, quantity, regime and quality of underground waters allow to produce documents necessary to make concepts of sustainable use and protection of water, to prepare and to draft plans for river-basin management, to perform the function of state water management authority and to supply information to the public. The underground water detection is carried out in the underground water formations and hydrogeological regions by hydrogeological surveys."

The Act No. 364/2004 Coll. also considers the power to establish a protection zone among the water management authority's responsibilities. This power is regulated by $\S 32$ Section 1 of the Act No. 364/2004 Coll., under which "For the protection of water yield and health safe water resources, the state water management authority shall determine protection zones based on the opinion of health protection authority. Where serious circumstances so require, the national water management authority may also determine protection zones for usable water resources and for water resources intended for drinking water offtake with the capacity lower than that defined for water resources. Along with this, the determined protection zones are also sanitary protection zones under a special regulation." In addition to water source protection zone, Act No. 364/2004 Coll. also regulates water structure protection zone in its $\S 55$ Section 2 , under which "In order to protect water structures, except public water supply and public sewerage systems, the state water management authority may, upon

${ }^{13}$ For further details, see Explanatory Report to the Draft Act No. 409/2014 Coll. 
the proposal of the water structure owner, determine the water structure protection zone, and prohibit or restrict construction of some buildings or activities therein, according to their nature. Within the water protection zone, the water structure owner is obliged to compensate the owner of property under the general regulations on damages."

The exercise of these powers by the state water management authority was subject to public law dispute which was judged by the Constitutional Court of the Slovak Republic before the above-cited $\S 21$ Section 7 letter b) of the Act No. 364/2004 Coll. was amended by the Act No. 409/ 2014 Coll. The owner of the water structure - the geothermal borehole "VRT VSČ - 1, V." - turned to the Regional Environmental Office in Prešov, following the conclusions and recommendations of the final report of the detailed hydrogeological survey approved by the Ministry of the Environment of the Slovak Republic, ${ }^{14}$ with a request to establish a water structure protection zone, on 9 July 2009. The owner proposed the establishment of water structure protection zone at a distance of $5 \mathrm{~km}$ from it. The Regional Environmental Office in Prešov, Department of Environmental Quality, refused to establish the water structure protection zone. ${ }^{15}$ The owner, therefore, appealed to the Ministry of the Environment of the Slovak Republic, Waters Division, Department of State Administration, Section of Water and Fisheries, which, however, upheld the decision of the Regional Environmental Office. ${ }^{16}$ The owner, therefore, appealed to the Regional Court in Bratislava with the request to review those decisions, which, however, also dismissed the owner's action. ${ }^{17}$ Following this, the owner appealed to the Supreme Court of the Slovak Republic, but here he did not succeed either, because the Supreme Court of the Slovak Republic upheld the decision of the Regional Court in Bratislava. ${ }^{18}$

Thereupon, the owner filed an individual complaint under the Article 127 of the Constitution of the Slovak Republic to the Constitutional

\footnotetext{
${ }^{14}$ See Decision of the Ministry of the Environment of the Slovak Republic of 18 August 2008, Ref. No. 92S2/2008-9.1.

${ }^{15}$ See Decision of the Ministry of the Environment of the Slovak Republic of 18 August 2008, Ref. No. 92S2/2008-9.1.

${ }^{16}$ See Decision of the Ministry of the Environment of the Slovak Republic of 25 May 2010, Ref. No. 6261/2010-8.1.

${ }^{17}$ For more details, see Judgement of the Regional Court in Bratislava of 7 December 2011, Ref. No. 2 S/272/2010-71.

${ }^{18}$ For further details, see Judgement of the Supreme Court of the Slovak Republic of 13 November 2012, Ref. No. 3 Sžp 6/2012.
} 
Court of the Slovak Republic. ${ }^{19}$ In the complaint, the owner claimed that the Supreme Court of the Slovak Republic violated his right to a fair trial by proceeding excessively restrictive in the interpretation of $\S 55$ Section 2 of the Act No. 364/2004 Coll. According to the owner, the Supreme Court of the Slovak Republic has, beyond the legal wording and meaning of this provision, restricted or excluded the possibility of applying this provision in the case of a specific type of water structure such as the geothermal borehole. This should, in his opinion, be in conflict with the previous case-law of the Constitutional Court of the Slovak Republic regulating the principles of interpreting legal standards by the general courts. ${ }^{20}$ Having excessively restrictive interpreted water structure protection zone, the general courts should have violated the owner's right to protect his investment, as it was not allowed to protect his investment spent for building of the above-mentioned geothermal borehole. In the same way, the courts should also have prevented the protection of future investments, which the owner will still have to pay to be able to use the geothermal borehole in practice. Interpretation of $\S 55$ Section 2 of the Act No. 364/2004 Coll., applied by the Supreme Court of the Slovak Republic, was, in owner's opinion, not correct, but was arbitrary. According to the owner, the Supreme Court of the Slovak Republic merely stated that the subject of the protection zone cannot be the prohibition of further exploration works in the defined territory, without specifying what specific considerations backed up this conclusion. According to the owner, the Supreme Court of the Slovak Republic did not take into account the systematic connection of the interpreted provision in its legal assessment of the case. In the challenged decision, it did not deal with another material fact which the owner objected against, and which, in his opinion, may significantly affect the interpretation of $\S 55$ Section 2 of the Act No. 364/ 2004 Coll. This concerned the issue of the seriousness of the final report approved by the Ministry of the Environment of the Slovak Republic as the central authority of the state water protection administration.

However, according to legal opinion of the Constitutional Court of the Slovak Republic, the Supreme Court of the Slovak Republic responded to the objections and challenges of the water structure owner in an appro-

${ }^{19}$ For further details, see Resolution of the Constitutional Court of the Slovak Republic of 19 March 2013, Ref. No. II. ÚS 193/2013-14.

${ }^{20}$ See e.g. Findings of the Constitutional Court of the Slovak Republic of 8 December 2010, Ref. No. I. ÚS 306/2010; and Findings of the Constitutional Court of the Slovak Republic of 11 December 2007, Ref. No. II. ÚS 341/07. 
priate, comprehensible and constitutionally acceptable manner and proceeded in accordance with the applicable procedural law. Therefore, the Constitutional Court of the Slovak Republic concluded that the Supreme Court of the Slovak Republic respected the rights of the water structure owner, and also respected the type and stage of proceedings in which the owner filed his claims, objections and challenges.

The Constitutional Court of the Slovak Republic thus preferred the opinion of the state water management authorities and both administrative courts that the protection of water structures under $\S 55$ Section 2 of the Act No.364/2004 Coll. serves for the immediate protection of water structure and its operability, not for the protection of the available volume of geothermal water. On these grounds, the state administration authority could not protect the quantitative parameters of underground water by determining the water structure protection zone. The state water management authorities also argued that, according to $\S 65$ of the Act No. 364/2004 Coll., "in issuing permits for special use of water, granting consents, providing opinions and other decisions, the state water management authorities are obligated to base their decisions on the results of detection and assessment of surface water and underground water occurrence, on water balance, program measures taken to improve the quality of surface water intended for drinking, on river basin management plans, on the Slovak Water Plan, on program of water harmful substances reduction and program of especially harmful substances reduction, and on concepts and development programs of water management." They did not have the power to determine the protection zone of water structure based on the grounds given by the water structure owner. However, they would have to take into account the quantitative protection of underground water with new entities applying for permit issue in the vicinity of the owner's existing water structure.

The Supreme Court of the Slovak Republic, therefore, supported the interpretation arguing that the objective of water structures protection under $\S 55$ Section 2 of the Act No. 364/2004 Coll. is to restrict construction activity or other activities that would harm the water structure itself in any way. It claimed that that provision begins with a phrase in order to protect the water structure, wherefore the protection zone referred to in the Article 55 Section 2 of the Act No. 364/2004 Coll. is intended to protect the water structure, and not to protect the usable volume of geothermal water, as requested by the water structure owner. The institute of water structure protection zone does not allow prohibiting permitting 
other areas for exploration and hydrogeological research by other persons in the given hydrogeological zone. The owner should have correctly referred to one of the meanings of the Act No. 364/2004 Coll., which is a purposeful, economical and sustainable use of water. However, in the opinion of the Supreme Court of the Slovak Republic, as far as the protection of geothermal waters is concerned, other provisions of the Act No. 364/2004 Coll. shall apply, not the provision of $\S 55$ Section 2 of the Act No. 364/2004 Coll. According to the Supreme Court of the Slovak Republic, to achieve this purpose of law as required by the water structure owner, $\S 21$ Section 7 of the Act No. 364/2004 Coll. or $\S 65$ of the Act No. 364/2004 Coll. should have been applied. Any further offtake of geothermal water shall be subject to the legislation on permitting procedure, and, in issuing permissions, the state water management authorities shall be bound to observe the level of underground water so that sustainable use of water resources and the proper function of related water formations would be maintained.

In issuing permits for special use of water, the state water management authorities proceed from the results of underground water occurrence surveys. Their obligation is to prevent the potential impact of new boreholes during exploration works on the existing geothermal water resources. Along with this, in proceedings under $\S 23$ Section 4 letter e) of the Act No.569/2007 Coll., the state water management authority, as a responsible body, does not have to grant its consent to the proposal of the exploration area, if negative offtakes of already permitted geothermal water offtake by a geological work could occur. Water structure or special use of water taken from geothermal resources shall be subject to permission procedure in which the state water management authorities assess individual aspects which may result in granting or non-granting a permit on a new water structure or special use of geothermal waters.

According to the Supreme Court of the Slovak Republic, these obligations are to secure efficient, economical and sustainable use of water. Such use cannot be secured by $\S 55$ Section 2 of the Act No. 364/2004 Coll., as required by the owner of the water structure.

However, the question then remains, why the lawmaker decided to amend the Act No.364/2004 Coll. $\S 21$ Section 7 letter b) by the Act No. 409/2014 Coll. by the institute of decision of the Ministry of the Environment of the Slovak Republic on approving the final report with the calculation of underground water volume? 
In granting permission on underground water offtake, the previous legislation did not require the consideration of the decision of the Ministry of the Environment of the Slovak Republic on approving the final report with the calculation of underground water volume referred to by the owner of the water structure. However, the judicial decision argued that the purpose which the water structure owner intended to achieve should be governed by the provision which the lawmaker later decided to complete with the arguments raised by the owner of the water structure. The question also remains the interpretation of $\S 55$ Section 2 of the Act No. 364/2004 Coll. The judicial decision was based on the introductory sentence of this provision, which the lawmaker expressed as follows: "In order to protect the water structure..." However, this provision allows the water management authority to delimit water structure protection zone upon the proposal of the water structure owner and, depending on its nature, to prohibit or to restrict not only the construction of certain structures, but also activities. The lawmaker thus stressed the nature of the water structure and allowed the state water management authority to prohibit also further activities in the protected zone, in addition to further construction works.

The nature of the geothermal borehole is subject to geothermal waters occurrence. Other activities may reduce the quantity and also the quality of geothermal waters. Although the argument of court case-law that other provisions of the Act No. 364/2004 Coll. should have regulated this protection is correct, the decision did not address the water structure owner's objections on the restrictive interpretation of the provision of the Article 55 Section 2 of the Act No. 364/2004 Coll. in which, in our opinion, the state administration could have decided - considering the existence of the final report approved by the Ministry of the Environment of the Slovak Republic - as requested by the water structure owner. The interpretation given by the court case-law was, therefore, in our view, excessively restrictive and did not take into account the requirement of economical use of natural resources and effective care of the environment, which means including geothermal waters protection, as included in the Article 44 Section 4 of the Constitution of the Slovak Republic, and, from year 2014, also in the Article 4 of the Constitution of the Slovak Republic. 


\section{Positive commitment of the state and other entities to economical use of waters, their ecological balance and effective management}

Positive commitment of the state to economical use of waters, their ecological balance and effective management was reflected, for example, in $\S 39$ of the Act No. 364/2004 Coll. In this provision, the lawmaker addressed the fundamental legal obligations of pollutants producers in relation to surface and underground water. The positive state's commitment has been manifested, in particular, in the adoption of legislation imposing obligations in relation to pollutants handling. These obligations have also been addressed by case-law which finds them legal if state administration draws consequences for breaching the duty under $\S 39$ Section 2 letters b), e) and f) and $\S 39$ Section 4 letter a) of the Act No. 364/2004 Coll. ${ }^{21}$ on the grounds that legal entity used pollutants storage facility not suitable for waters protection. This is the case, for example, of agricultural buildings from the 1980s, originally used to store silage feed and now to store fertilizers. The court's decision confirmed that such proceeding of the operator as a legal entity constitute a breach of the obligation related to the protection of surface and underground water, since the use of equipment not technically fitting to prevent the leakage of pollutants into the soil and endangering water quality gives grounds to hold a legal person liable for the breach of its obligations in relation to water protection.

${ }^{21}$ Under $\S 39$ Section 2 letters b), e) and f) of the Act No. 364/2004 Coll. on Waters, and on Amendment to the Act of the Slovak National Council No. 372/1990 Coll. on Offenses, as amended, "The person handling pollutants shall be obliged to observe special regulations stipulating conditions under which such substances should be handled regarding surface and underground water quality protection. Considering water protection, if such treatment is not governed by specific regulations, the person handling such pollutants shall take necessary measures to ensure that they do not enter or endanger surface or underground water. In particular, these measures include: [...] (b) use only equipment, technological processes or other means of handling pollutants that are also suitable for the protection of water; [...] (e) establish and properly operate effective control systems to detect leakage in a timely manner; [...] (f) other measures necessary according to the nature of the pollutant and the way it is handled." According to $\S 39$ Section 4 letter a) of the Act No. 364/2004 Coll. on Waters, and on Amendment to the Act of the Slovak National Council No. 372/1990 Coll. on Offenses, as amended, "That who in the production process or other activity regularly handles solid pollutants in quantities of over 1 tonne, or liquid pollutants in quantities of over $1 \mathrm{~m}^{3}$ or handles solid priority hazardous substances in quantities of over 0,3 tonnes, or liquid priority hazardous substances in quantities of over $0,3 \mathrm{~m}^{3}$, shall, in addition to the measures referred to in paragraph 2, also take the following measures: [...] (a) draw up a preventive action plan to prevent uncontrolled leakage of pollutants; substances for the environment and for action to be taken in the event of their leakage (hereinafter referred to as the "emergency plan"), submit it to the national water authority for approval and inform employees thereof,..." 
At the same time, the state administration is obliged to impose administrative accountability for this act. ${ }^{22}$

In addition to the obligations related to handling pollutants, these provisions also impose an obligation on operators to draw up an emergency plan, to submit it to the national water administration authority for approval and to make available to their employees to get acquainted with. Therefore, the case-law considers, with equal seriousness, the cases in which the operator has not made available the relevant state water management authority approved "emergency plan" for the premises in which the operator operates including handling dangerous substances at the time the state administration authority performs an inspection.

If, at the time of inspection, the operator submits the operating instructions for the storage and handling of dangerous substances and emergency plan applicable to the former operation of the inspected facility - the storage facility of flammable matters, which documents, however, cannot replace the statutory emergency plan, as each of them performs a different function, the case-law considers this to be a violation of the Act No. 364/2004 Coll. The operator is obliged by the Act No. 364/ 2004 to have an emergency plan drawn up and approved for the activity performed in site and for the time given, wherefore the emergency plan for the former flammable storage facility cannot be recognized. The caselaw sees operating instructions for the storage and handling dangerous matters with other than the emergency plan purpose, in the same way. The operating instructions for the storage and handling of dangerous matters are used to secure the proper operation of the warehouse with hazardous matters. On the contrary, the emergency plan, the particulars of which are stated in Annex to the Decree of the Ministry of the Environment of the Slovak Republic No. 100/2005 Coll., lies down details of handling hazardous matters, requirements of the emergency plan and the procedure for dealing with extraordinary water deterioration.

The emergency plan includes preventive actions to be taken to prevent the uncontrolled discharge and actions to take in case hazardous matters leak into the environment, for the entity concerned. This obligation is also a reflection of the general preventive obligation laid down in the Article 44 Section 3 of the Constitution of the Slovak Republic, according to which "No one may endanger or damage the environment, nat-

\footnotetext{
${ }^{22}$ For further details, see Judgement of the Supreme Court of the Slovak Republic of 1 April 2015, Ref. No. 3 Sžo 30/2014.
} 
ural resources and the cultural heritage beyond the extent laid down by law." Therefore, if the operator submits this document after the state water management authority had carried out the inspection, this should not affect the cessation of operator's administrative liability. ${ }^{23}$

The positive commitment of the state and other entities in relation to water quality was also included in legislation on the discharge of waste substances into surface waters. The Act No. 364/2004 Coll. provides conditions for the universal protection of waters, including aquatic ecosystems and water-dependent ecosystems in the country, conservation or improvement of water status, efficient, economical and sustainable use of waters, river basin management and improvement of the environment and its components, reducing the adverse effects of floods and drought, securing watercourse functions and water safety. The legislation also regulates water quality requirements. The discharge of waste substances makes the essence of the special use of water for which the legislation requires issuing a special permit under $\S 21$ Section 1 letter c) of the Act No. 364/2004 Coll. ${ }^{24}$

Thus, the operator commits a breach of the above-stated obligations under the Act No. 364/2004 Coll. by discharging waste water from the emergency accumulation tank into the surface water of the watercourse, in contradiction to the permit issued by the state water management authority. In such a permit, the water management authority shall determine the permitted amount and method of measuring the volume of discharged waste water, permitted non-exceedable concentration and balance values of individual pollution indicators of discharged waste water, place and method of waste water discharge, place and time of sampling, frequency of sampling, method of sampling and method of checking individual indicators. In that case, the state water management authority has, according to $\S 74$ Section 1 letter e) of the Act No. 364/2004 Coll., the obligation to secure liability and to impose a fine on a legal person or natural person - entrepreneur that has discharged waste water or special water into surface waters or underground waters, or has discharged industrial

${ }^{23}$ For further details, see Judgement of the Supreme Court of the Slovak Republic of 29 September 2011, Ref. No. 5 Sžp 10/2011.

${ }^{24}$ Under § 21 Section 1 letter c) of the Act No. 364/2004 Coll. on Waters, and on Amendment to the Act of the Slovak National Council No. 372/1990 Coll. on Offenses, as amended, "Permit for special use of water shall be required unless it is a use of waters pursuant to $\S 18$ to 20 (c) for the discharge of waste waters, special waters and geothermal waters into surface or underground waters..." 
waste water or special water containing particularly harmful substances into the public sewerage without the permit of the state water management authority, or in conflict with it. Otherwise, it commits a breach of its positive obligation under the Constitution of the Slovak Republic to secure economical use of natural resources. ${ }^{25}$

\section{Conclusions}

Water is a substance vital for any form of life on the Earth. The environment it creates is essential for life and life without water is not possible. Approximately $60 \%$ of the human body is water. Life on the Earth is believed to have originated in water. The Earth is the planet with the second largest water content in the Solar System. In principle, water can be said to be independent from a man. However, this does not apply viceversa. All living organisms are dependent on water and are subject to gradual extinction without water. In the area of public international law, the human right to water has been recognized by many international documents, including international human rights treaties, declarations and other standards. The Joint Monitoring Program of the World Health Organization and the United Nations International Children's Emergency Fund on Water Supply, Sanitation and Safe Sanitary Conditions continually estimates that over 748 million people still do not have guaranteed easy access to better sources of drinking water, and over a third of the world's population, i.e. approximately 2.5 billion people still do not use the modern sanitation system as known to the people of the developed countries on the Earth. Water is essential for a variety of purposes, in addition to personal and domestic use, for example, also for the implementation of the rights embedded in the International Covenant on Economic, Social and Cultural Rights. For example, water is essential in food production (right to adequate nutrition) and to ensure environmental hygiene (right to health). Water is essential for the development of a person's individuality (right to education), to ensure sustenance (right to work) and to follow cultural traditions (right to participate in cultural life).

It must, therefore, be concluded that the effective regulation of water management and embedding the right of access to water and sanitation services shall go hand in hand with the promotion of education. Without effective education, it will not be possible to effectively enforce legal and

\footnotetext{
${ }^{25}$ For further details, see Judgement of the Supreme Court of the Slovak Republic of 29 September 2011, Ref. No. 5 Sžp 6/2011.
} 
other water management instruments establishing the right of access to water. This conclusion is also stressed by the United Nations Organization within the United Nations Water Program promoting efficient, economical and sustainable use of clean and drinking water, which is not possible without providing quality education to future generations in water management. Water can, in legal terms, be a strategic object of protecting the interests of the state and society. However, its promotion will be very difficult without an effective spreading of knowledge, especially among children and young people, who shall make use of clean and drinking water in the future.

\section{References}

Act No. 17/1992 Coll. on the Environment, as amended.

Act No. 364/2004 Coll. on Waters, and on Amendment to the Act of the Slovak National Council No. 372/1990 Coll. on Offenses, as amended.

Act No. 569/2007 Coll. on Geological Works, as amended.

Constitutional Act No. 227/2002 Coll. on State Security at the Time of War, State of War, State of Emergency and State of Crisis, as amended.

Constitutional Act No. 460/1992 Coll. Constitution of the Slovak Republic, as amended.

DALE BRITTAIN, C. Water in the Middle Ages. In: Life in the Middle Ages [online]. 2015-05-28 [cit. 2019-12-09]. Available at: http://cdale brittain.blogspot.com/2015/05/water-in-middle-ages.html.

Decision of the Ministry of the Environment of the Slovak Republic of 18 August 2008, Ref. No. 92S2/2008-9.1.

Decision of the Ministry of the Environment of the Slovak Republic of 25 May 2010, Ref. No. 6261/2010-8.1.

Decree of the Ministry of the Environment of the Slovak Republic No. 100/ 2005 Coll.

Explanatory Report to the Draft Act No. 409/2014 Coll.

Findings of the Constitutional Court of the Slovak Republic of 11 December 2007, Ref. No. II. ÚS 341/07.

Findings of the Constitutional Court of the Slovak Republic of 8 December 2010, Ref. No. I. ÚS 306/2010. 
Judgement of the Regional Court in Bratislava of 7 December 2011, Ref. No. 2 S/272/2010-71.

Judgement of the Supreme Court of the Slovak Republic of 29 September 2011, Ref. No. 5 Sžp 6/2011.

Judgement of the Supreme Court of the Slovak Republic of 29 September 2011, Ref. No. 5 Sžp 10/2011.

Judgement of the Supreme Court of the Slovak Republic of 13 November 2012, Ref. No. 3 Sžp 6/2012.

Judgement of the Supreme Court of the Slovak Republic of 1 April 2015, Ref. No. 3 Sžo 30/2014.

LACLAVÍKOVÁ, M. and A. ŠVECOVÁ. Pramene práva na území Slovenska I.: Od najstarších čias do roku 1790 [Sources of Law in Slovakia I.: From the Oldest Times till 1790]. 1. vyd. Trnava: Typi Universitatis Tyrnaviensis, 2007. 415 p. ISBN 978-80-8082-153-1.

LLORIS, F. B. An Irrigation Decree from Roman Spain: The Lex Rivi Hiberiensis. The Journal of Roman Studies [online]. 2006, vol. 96, pp. 147197 [cit. 2019-12-09]. ISSN 1753-528X. Available at: https://doi.org/ 10.3815/000000006784016242.

Regál [Regal]. In: Pamiatky na Slovensku [Sights in Slovakia] [online]. 2019 [cit. 2019-12-09]. Available at: http://www.pamiatkynaslovensku.sk/regal.

Resolution of the Constitutional Court of the Slovak Republic of 19 March 2013, Ref. No. II. ÚS 193/2013-14.

VOJÁČEK, L., J. KOLÁRIK and T. GÁBRIŠ. Československé právne dejiny [Czechoslovak History of Law]. 2. preprac. vyd. Žilina: Eurokódex, 2013. 423 p. ISBN 978-80-89447-99-2.

WILSON, A. Water, Power and Culture in the Roman and Byzantine Worlds: An Introduction. Water History [online]. 2012, vol. 4, no. 1, pp. 1-9 [cit. 2019-12-09]. ISSN 1877-7244. Available at: https://doi. org/10.1007/s12685-012-0050-2.

Doc. JUDr. Michal Maslen, PhD.

Faculty of Law Trnava University in Trnava Kollárova 10 
91701 Trnava

Slovak Republic

michal.maslen@truni.sk

(D) https://orcid.org/0000-0001-7496-2227 